RANKA GAŠIĆ, viši naučni saradnik

Institut za savremenu istoriju

UDK 316.75:711.4(497.11)"19"

Beograd, Trg Nikole Pašića 11

$94: 316.334 .56(497.11)^{\prime \prime} 19 "$

\title{
THE OLD BELGRADE FAIRGROUND - JUDENLAGER SEMLIN. A PLACE OF INTENTIONAL OBLIVION?*
}

\begin{abstract}
The short survey of the Old Belgrade Fairground territory and history, with an emphasis on the camp as a symbol of the place throughout history. Article elaborates present state of oblivion and neglection of the Fairground place by the authorities and the plans of its revival.
\end{abstract}

Key Words: The Old Belgrade Fairground, camp, symbol of the place, Judenlager Semlin, New Belgrade

The territory of the Belgrade Old Fairground has a very peculiar history. Although situated at the very center of the city, at the river bank, between two very busy traffic arteries, the place is totally neglected, as if it has fallen into complete oblivion. Like the rest of the „New Belgrade“ (modern city between the Sava left bank, the Danube right bank and the old city of Zemun) this was never an area of settlement until very recently (since the 1950s). However, unlike New Belgrade, which is today an office zone, and one of the most prosperous municipalities in Serbia, it seems that the location of the Old Fairground was never transformed into an area fit for settlement, nor was it given any other specific purpose in the last 50 years. What follows is a very brief survey of what was going on at this place in the last 300 years, and elaboration on the possible reasons why, despite the fact that it lays in the heart of the office zone, surrounded with two busy bridges, it remains beyond the scope of Belgrade population and of the municipal authorities.

This place has undergone several transformations, as to its purpose. First and foremost, the quality of the soil is the main reason why there was no lasting

${ }^{*}$ The paper has been presented at the $10^{\text {th }}$ International SIEF Congress - People Make Places, Lisbon, Portugal, on April 18th 2011. This article is also a part of the Serbian Ministry of Education and Science Project No. 177016, Serbian 20th Century Society between Democracy and Dictatorship (Srpsko društvo u jugoslovenskoj državi u 20. veku-Iizmeđu demokratije i diktature). 
settlement here until the 20th century. The terrain is susceptible for flooding, and it was a difficult ground not only for the settlers, but for the armies, as well. Secondly, in the minds of the Belgrade population, the place had a specific significance as a border between two wolds and two civilisations, which raised both the fear of the unknown and the hope for salvation. It was both the place the danger was coming from, and the crossing of the political emmigrants from both sides (but, also, of the fugitives from the justice). This dual symbolics is very important for the history of the place in general. In the 20th century, in particular, which is an era of exclusive ideologies, the story of the Old Fairground was still marked by this dichotomy, this time between the „dark past“ and the „bright future".

Before Serbia became an independent state, during the 19th century, the Sava left bank was the stage of wars between the Habsburg and the Ottoman empire. From the late 17th to the late 18th century the Habsburg troops laid siege on Belgrade several times (in 1688,1693, 1717, 1788-89). During the 1688 siege a pontoon bridge was laid approximatly at this place, whereas the Austrian military camp was erected upstream. During the 1693 siege the road on wooden staples was build over the moor, all the way from Zemun to the pontoon bridge, which was the fist time in history that the direct line of land transportation was established between those two cities. It was called the Long Bridge, and it was standing until 1724. Until then, as well as almost for two centureis after, there was only river transportation at times of both war and piece. ${ }^{1}$ This line coincides with the modern boulevard that leads today directly from the Sava bridge to Zemun. During the 1717 siege, the Austrian army mostly attacked Belgrade from the Danube side, but at this very place, a redoubt was erected for the purpose of artillery attack on the city. ${ }^{2}$ This object can be seen on various Austrian military maps of the time. Another fortification of this kind was erected here again in 1789, provided with cannons, when the Austrian general Laudon took Belgrade after heavy bombardment from this spot. ${ }^{3}$

The second phase starts after the 1918, which marked the end of the WWI and the formation of the new Kingdom of Yugoslavia. It was certainly a completely new era in the history of Belgrade, since from this time onwards it ceased to be a border city and became a capital of a much larger state. The vast plain across the city suddenly opened new perspectives for expansion. Like any

${ }^{1}$ Veselinović, R., Ratovi Turske i Austrije 1683-1717 (The Habsburg-Ottoman Wars 1683-1717), in: Istorija Beograda I (History of Belgrade I), Beograd 1974, pp. 465-517, here pp. 470-472, pp. 500-501; Nikolić, Z., Radonjić, M., Tajna Novog Beograda (The Secret of New Belgrade), Belgrade 2010, pp. 80-82.

${ }^{2}$ Veselinović, R., Beograd pod vlašću Austrije od 1717. do 1739. godine (Belgrade under the Reign of the Habsburg Monarchy), in: Istorija Beograda I, Belgrade 1974, pp. 523-571, here pp. 523-527.

${ }^{3}$ Čubrilović, V., Grad pred srpsku revoluciju 1804 (The City on the Eve of the Serbian Revolution in 1804), in: Istorija Beograda I, Belgrade 1974, pp. 717-758, here pp. 726-732. 
new state, the Kingdom of Yugoslavia had a propensity for representation, and so the city of Belgrade gained importance. At that point began the era of great optimism with the paradigm of ,bright future“, whose scope was very limited by poor financial means. Almost immediately the planning of the other Sava bank became an important issue. The international open competition for the Masterplan of Belgrade was anoounced in 1922. The plan anticipated building on the Sava left bank. ${ }^{4}$ Two of the competing plans reflected the utmost propensity for representation, bordering on megalomania. One of them was made by the Belgrade city architect, Djordje Kovaljevski, and was called ,The Illustrative plan of the Sava left bank city". It anticipated a new settlement on the other Sava bank intertwining with the city of Zemun, the Great War Island and the old city of Belgrade (the town nucleus). ${ }^{5}$ However, the other plan done by a group of Austrian architects, called „Singidunum novissima“, anticipated a modern city with a grid plan, a lot of parks (that were lacking in the old city) and the Fairground. According to this plan, the new city would stand apart from the old one, as a separate body in every respect. These were mostly utopian notions about the future of the city, aimed primarily at representation. Since they were not realized, the Old Fairground is the only part that was carried out.

The terrain on which the Fairground should have been built was a longterm subject of public debate in the interwar period. Both Yugoslav and foreign businessmen attended exhibitions at the Zagreb and Ljubljana fairgrounds. The most important precondition for building on the Sava left bank was, of course, the transportation. Until the WWI, the only land communication with Central Europe was the railway bridge, erected in $1884 .^{6}$ Although the river traffic was very busy, the lack of land communications prevented any serious attempt to expand the city over the river. After the bridge over Sava was built in 1935, there were many reasons in favour of building the Fairground across the river: the terrain was close enough to the center of the city, the access became easy, the position was favourable in terms of communication, there were ample possibilities of expansion and, most importantly, it was not neccessary to exproriate private lots, since the ground was a municipal property. ${ }^{7}$

So, the building of the Fairground started very soon after the bridge was erected - in October 1936. In December 1935 the Belgrade City Council finally decided to let this terrain to the Belgrade Society for Organizing Fairs and Exhi-

${ }^{4}$ Anonim, Savska plaža od železničkog mosta do ušća Save u Dunav pretvoriće se u novo predgrađe Prestonice (The Sava Beach between the Railway Bridge and the Sava and the Danube Confluence to be the New Suburb of the Capital), in: Vreme, 12. 10. 1931.

5 Blagojević, Lj., Novi Beograd. Osporeni modernizam (Contested Modernism), Belgrade 2007, pp. 19-23.

${ }^{6}$ Blagojević, Lj., op. cit., 18.

${ }^{7}$ Popović, D. M., The Belgrade Fairground, in: Beogradske opštinske novine (BON), 11/12 (1935), pp. 656-661. 
bitions (Društvo za priređivanje sajma i izložbi), founded as early as in 1923. It was a vast piece of land (some $36 \mathrm{ha}$ ), between the two bridges. ${ }^{8}$ The Society was given a loan of 6 million dinars for this purpose, and the whole undertaking was financed with the loans of the City Council, of the Municipal Savings Bank, and of various contributions made by private funds and foundations, trade chambers and private citizens. ${ }^{9}$ Since the international competition did not produce an acceptable solution, the planning was assigned to three city architects (Milivoje Tričković, Djordje Lukić and Rajko Tatić). The whole compound consisted of five major pavilions, with the one built by the Nikola Spasic Foundation, the central tower, the restaurant, the management building and some auxiliary buildings. When the opening ceremony was held in July 1937, not all of the structures were yet finished. The pavilions of foreign countries were already erected - those of Italy, Hungary, Romania, Tchekoslowakia, whereas the ones of Turkey and Germany were erected in 1938 and 1939, respectively. All foreign pavilions were designed by the architects from those countries. ${ }^{10}$ The magnificent pavilion of Nikola Spasic Foundation had a large gallery and a hall with special illumination designed for paintings exhibition. Some of the pavilions were also property of private citizens. The agricultural fairground and an amusement park were anticipated, but were never realized. ${ }^{11}$

Since the first Belgrade international fair in 1937, this place was very attractive to Belgrade citizens, who kept going there en masse. During 1937 some 250000 people visited the Fairground, and in 1940. there were almost 290000 visitors (the Autumn Exhibition alone reached a record number of 170000 visitors), which was indeed a big number for the city of altogether 350000 inhabitants. ${ }^{12}$ The information desk in the town center was open from 6 a. m. to 12. p. $\mathrm{m}$, the visitors were accommodated in the hotels and private lodgings, and a special bus line was organized from the railway station to the Fairground. The Belgrade Fair became one of the most important in the southeast Europe. Each year a Spring and an Autumn Exhibition, and many other manifestations have been organized here - international automobile fair, concerts, sports games, fashion weeks, etc. ${ }^{13}$ Some of the most attractive manifestations were the First Internati-

${ }^{8}$ The first Belgrade fair was held on the 14 ha wide territory. (Ristanović, S. V., Novi Beograd. Graditeljski poduhvat veka (New Belgrade. A Building Enterprise of the Century), Belgrade 2009, pp. 516-521)

${ }^{9}$ Anonim, Rešeno je da opština ustupi zemljište na levoj obali Save za Sajmište (The City Awards the Allotment at the left Sava bank for the Fairground) in: Politika, 19. 12. 1935; Blagojević, Lj., op. cit., p. 255. Ristanović, S. V., op. cit., pp. 516-521.

${ }^{10}$ Blagojević. Lj., op. cit., p. 256; Sekulić. A., Prvi Beogradski sajam između Prvog i Drugog svetskog rata (The First Belgrade Fairground between the World Wars), in: Godišnjak grada Beograda IV (1957), pp. 587-597; Anonim, Osvećeni su temelji Beogradskog sajma (Consecration of the Belgrade Fairground Foundations), in: Pravda, 7. 6. 1937.

${ }^{11}$ Ristanović, S. V., op. cit., pp. 516-521.

${ }^{12}$ Blagojević, Lj., op. cit., pp. 254-259.

${ }^{13}$ Ristanović, S. V., op. cit., pp. 516-521. 
onal Aircraft Exhibition in May 1938, with the German Sqadron of 38 airplanes and an air show, and the first TV projection in the Phillips pavilion, also in 1938. ${ }^{14}$ These fairs produced an impression on Belgraders similar to the world exhibitions of the 19th century - a new, mass industry of propaganda. The Fairground itself looked like a big advertisment - with the illuminated bridge, sparkling pavilions and the central tower all in blue and yellow lights. This whole propaganda industry was inextricably linked with the political context of the late 1930s. The war was already going on in Europe when the new model architecture of Albert Speer was represented at the Belgrade Fairground. ${ }^{15}$ Besides, the Old Fairground in a way opened a perspective for the future New Belgrade in terms of city planning, because all of its objects were geometrically disposed and connected into a harmonious unit. ${ }^{16}$

The new phase in the history of the place begins with the outbreak of the WWII in Yugoslavia (in April 1941). The whole complex was turned into a camp. However, a bad omen of what was going to happen took place as early as in September 1940 when, according to the agreement between the Third Reich and the Soviet Union, the Germans from Bessarabia have been dislocated and sent to Poland. On their way, they were accommodated in Belgrade, at the Sava left bank, just next to the Fairground. For this purpose, a large camp has been erected with 69 barracks, and within a few months (until December 1940) some 12000 German civilians were temporarily accommodated here. ${ }^{17}$ In this way, the shadow of the war has already appeared over the place, and two different symbolic meanings it had in history came into a close contact - the camp like the omen of war, and the sparkling exhibitions, the triumph of modernism, laid one next to the other. ${ }^{18}$

When the country was occupied by the Nazi forces, the left Sava bank was once again separated from the city, and put under the jurisdiction of the Independent State of Croatia. The period of wars and camps now repeated itself in a more drastic way. The Fairground complex was turned into a concentration camp for the members of the resistance, for the Jews (Judenlager Semlin), and finally (from 1942 to 1944) into a reception point (Anhaltelager) for the prisoners sent to forced labour camps in Germany. This complex was used to that purpose because of its perfect geostrategic position and because it was only slightly damaged during the aerial attack on Belgrade. The space

${ }^{14}$ Nikolić, Z., Radonjić, M., op. cit., pp. 156-167; Blagojević, Lj., op. cit., pp. 254-259:

${ }^{15}$ At the same time, in 1940, the German architect, Werner March, designed a plan for the Belgrade fortress in the style of Nazi monumental architecture. Interestingly enough, he was invited by communist authorities after the war to participate in the planning of New Belgrade.

${ }^{16}$ Blagojević, Lj., op. cit., pp. 254-259: Ristanović, S. V., op. cit., p. 516; Nikolić, Z., Radonjić, M., op. cit., pp. 156-167.

${ }^{17}$ At this place today stands a big shopping mall.

${ }^{18}$ Nikolić, Z., Radonjić, M., op. cit., pp. 242-249; Blagojević, Lj., op. cit., pp. 259-260. 
was ample, and it was estimated to be able to accommodate a few thousand people.

Most of the Jewish male population of Belgrade were imprisoned and shot in another place (Topovske šupe), and the women and children, as well as the old and the sick, were transported to the Fairground. This was a camp for Jews (the only one in Europe with that name, although Jews were killed in all of them). It was run by Gestapo, although it was situated on the territory of the Independent State of Croatia. The total number of Jews imprisoned and killed in this camp is estimated at about 6400 (there were also some 600 Roma people, who were mostly released by March 1942). About $10 \%$ died due to inhuman life conditions. The view on the Fairground was extremely dramatic for Belgrade population, especially when the deceased prisoners were carried across the frozen river, for all the people to see. The trauma was all the worse for the prisoners, to see the city so near, and so unattainable. ${ }^{19}$

In the spring of 1942 it was decided by the Nazi authorities in Berlin that the resistance in Yugoslavia must be supressed, and that the resistance members must be captured and transported, among other places, to the Judenlager Semlin, from where they should have been sent to forced labour camps in Germany. To that end, a special device has been sent to Belgrade from Berlin - a mobile gas chamber, which was in fact, the first experiment with a gas chamber made in the Third Reich. It was a truck in which the rest of the prisoners were put in large groups. It drove through the city, heading to another prisoners camp outside of it, where the dead were being buried in mass graves. The number of people killed in this way is estimated at about 300 a day, for the period of two months (April and May 1942). ${ }^{20}$ After the almost total extermination of the Belgrade Jews, the camp changed its prupose in May 1942, when it became a reception point for political prisoners, members of the resistance, but also people who were young and fit for hard work, sent for forced labour. Sometimes, though, these people were shot as a reprisal measure against the resistance. Since September 1943, when Italy signed an armistrice, there were also Greeks and Albanians imprisoned here on their way to German camps. ${ }^{21}$ This compound was bombed by the Allied Forces in April 1944, when 200 prisoners lost their lives, and the buildings were heavily damaged. In May 1944 the Croatian police took the camp, but left it soon, since the liberation forces were making a quick progress towards Belgrade. Almost all the pavilions were demolished or heavily damaged from April to September 1944, the only ones remaining were the administration building, the Italian pavi-

${ }^{19}$ Lebl, A., Reagovanja. Logor sa rasnim imenom (Comment. A Camp with a Racial Name), in: Danas, 26. 3. 2003 (citation in: Blagojević, Lj., op. cit., p. 259).

${ }^{20} 83,1 \%$ of the total Jewish population of Serbia was killed in Holocaust, some $42,5 \%$ out of the total in this camp. (Koljanin, M., Nemački logor na beogradskom Sajmištu 1941-1944 (The German Camp at the Belgrade Fairground 1941-1944), Belgrade 1992, p. 447.

${ }^{21}$ Koljanin, M., op. cit., pp. 448, 449; Lebl, A., op. cit. 
lion, the central tower and the Spasic Foundation pavilion. The estimated number of people who stayed in the camp during the war is about $31.972 .{ }^{22}$

The liberation of Yugoslavia after the WWII marked a whole new beginning for the country. A new political and ideological order was established. Creating a „new“ and a „better" world meant mostly a total annihilation of the past and a fresh, new start from the ,zero point". This is how the building of New Belgrade began, a modern city on the left bank that was planned before the war, but that was now being built in a different way - by „youth brigades“, oficially on the volontary basis, but in a given political context it was something between the volontary and the forced labour. From 1946 to 1952 about a million young people from then Yugoslavia worked on the terrains between Belgrade and Zemun, on the place that for the first time in history became a human settlement. They were sheltered in the youth camp, and the brigades were organized in a military style. The Fairground was the Headquarters of the youth brigades, as the only exsiting object fit for this purpose. ${ }^{23}$ So, the camp again emerges as a symbol of the place. It is interesting, though, that this was precisely the moment when the period of the (intentional?) oblivion started.

The authorities were decidedly against rebuilding the fairground at the same place. So the new fairground was built in the 1950s on the Sava right bank, a few hunderd meters upstream. The objects of the Old Fairground are continuosly being used, but until the 1990s this terrain has constantly been left out of the sight of city planners and architects. No attempt has been made in terms of conservation or reconstrucion. Was that, perhaps, an intentional oblivion of the war crimes, and a decision to concentrate on the „bright future“? It is a neglected and forgotten dwelling of the artists, firms and warehouses. Since 1950s some very prominents artists opened their studios here and many of them are still here today. ${ }^{24}$ There are people living here, completely aware of what was going on there in the past, feeling very uneasy about it. The space is not integrated either in the old or in the new part of the city.

Yet, some architects participating in various competitions, made plans for the Old Fairground. A Modern Gallery was planned here in 1948, a Military Museum in 1949-50. and the Opera in $1971 .{ }^{25}$ However from the late 1980s, some serious debates started on the subject. In 1987 the complex was classified as a place of „cultural heritage“ which, at least, indicated that the authorities had some serious plans about it, and that the end of its informal use will not be tolerated

${ }^{22}$ Koljanin, M., op. cit., pp. 449, 450; Blagojević, Lj., op. cit., pp. 259-260.

${ }^{23}$ Blagojević, Lj., op. cit., pp. 262-266. In the early 1950s the building of New Belgrade by youth brigades was discontinued, and the construction firms took over.

${ }_{24}^{24}$ Blagojević, Lj., op. cit., pp. 260-261; Ristanović, S. V., op. cit., pp. 518-519.

${ }^{25}$ Nothing of the above mentioned was realized: the Military Museum is located at the fortress, the Modern Gallery is, according to the city plan, due to be erected in the center of the city (at the Republic Square), whereas the Opera is due to be at New Belgrade, althougn not at the Old Fairground, but downstream. 
for much longer. In 1992. the City Council enacted a detailed urban plan of the commemorative complex, by which everything should be turned into its former state, before the WWII, allowing, however, that some spots could be used for exhibitions. A museum of genocide is also planned here. ${ }^{26}$ The only exsisting commemorative object is a monument erected in 1995. In the last few years several manifestations have been organized in order to draw the attention of the public to this problem, such as the Days of the Old Fairground Conference at the National Museum in April 2006, and an exhibition organized by the Belgrade Society of City Planners during the 30th Salon of Architecture in 2008. A wide consensus has been reached as to the neccessity of opening a commemorative museum. The prominent Belgrade architect, Mihajlo Mitrović, has designed a memorial museum in the central tower. ${ }^{27}$

Is this, after all, a place of intentional oblivion, and if so, what are the possible reasons?

One of them could be money. Is there something to gain, could some profit be made out of it? The business people are certainly not happy about the idea of a commemorative museum. During the 1990s a scandalous affair took place when the Spasic Foundation pavilion, which used to be a camp hospital during the war, was sold to a private investor who meant to open a night club there, which was fortunately prevented by citizens protest. Yet, it seems that there are other, more probable reasons. Are they political? The socialist Yugoslavia seem to have glorified the heroism of the active resistance members more than it has paid respects to civilian victims of war, whereas in the period after disintegration (from the 1990s onwards) the state of Serbia was more interested in the Serb victims of war and genocide. The historian Jovan Byford claims that the holocaust in Yugoslavia was never given due attention, that it was always put into the context of other victims. That was, of course, due to the interethnic frictions within former Yugoslavia. The monument stays at the river bank, somewhat apart from the rest of the complex, as if the connection between history and the memory of it is broken.

Another problem is facing the past, which is one of the important social and political issues in the countries of ex Yugoslavia today. Is the fact that such a camp exsisted so near the city was too much to bear? There are other commemorative museums in Belgrade that used to be prisons and places of mass execution, but they all lay outside the city, at a „proper“ distance. The creators of the „,better future" and a new society maybe would not have had the place of holocaust so close to their „city of the future“. Maybe they were not ready to allow past reality to interfere with the ideal image of the future.

Finally, this piece of land has its own symbolic significance. It was the theater of wars and camps - the organized, totalitarian and collective way of life.

\footnotetext{
${ }^{26}$ Ristanović, S. V., op. cit., pp. 519-521; Blagojević, Lj., op. cit., pp. 265-266.

${ }^{27}$ Ristanović, S. V., op. cit., pp. 519-521.
} 
On the other hand, it was the place of projecting a „better future“, modernism in a form of technical progress and comforts of life (as suggested by the fairs before the war, and the new, modern city after the war). A modern city was built on the „no man's land“, on a flooded field between two old cities (Belgrade and Zemun), where no human settlement ever existed before. For a long time, New Belgrade was nothing more than a mass dormitory, a place where no other activities exsited save dwelling. Was it not again a sort of camp? In the early communist era the future was seen as a tabula rasa. Maybe in view of that consideration, the place of the „dark past" had to be supressed and had to fall into oblivion.

However, it is an important place for the Belgrade urban heritage. It is a link between the old and the new city, with its particular environmental, stylistic and ecological charachteritics, with its historical and commemorative significance. It is also a specimen of the city planning avant-garde of the 1920 s, with the elements of the traditional city, like squares, streets and blocks. It is today a place of misery, of life on the margins. Belgrade seems not to notice these dwellers who exsist in the blind corner of the society. ${ }^{28}$

${ }^{28}$ Ristanović, S. V., op. cit., pp. 518-519. 


\section{Ranka Gašić}

\section{STARO SAJMIŠTE U BEOGRADU - JUDENLAGER SEMLIN. MESTO NAMERNOG ZABORAVA?}

\section{Rezime}

U kolektivnom sećanju Beograđana ovo područje je predstavljalo simbol vrlo različitih ideja tokom istorije. U daljoj prošlosti (do 1918) nalazilo se na granici dveju civilizacija i država, što se ponovilo tokom Drugog svetskog rata. Posle stvaranja Kraljevine SHS/Jugoslavije 1918. godine otvorene su brojne mogućnosti za korišćenje terena preko Save, pa je tako u drugoj polovini 30-ih godina ovde izgrađeno Sajmište, koje je bilo simbol modernizma, evropeizacije, masovne industrije i komercijalnog uspeha. Kao koncentracioni logor za vreme Drugog svetskog rata, ovo mesto je postalo simbol nacističke okupacije i stradanja civila. Nova komunistička ideologija pokušala je da izbriše sećanja na „mračnu prošlost" i da promoviše ideje o boljoj budućnosti i sasvim novom početku. $\mathrm{Na}$ teritoriji između Zemuna i Beograda, na levoj obali Save, izgrađen je novi grad, u duhu arhitekture moderne, dok je teren Starog sajmišta, usred novog i modernog grada, ostao zaboravljen u narednih 60 godina. Iako se nalazi veoma blizu centralnog gradskog jezgra, a bilo je i predmet mnogih razgovora i debata $u$ javnosti, kao i planova arhitekata i urbanista u poslednjih dvadeset godina, na revitalizaciji ovog područja još uvek ništa nije urađeno. Novo sajmište u Beogradu podignuto je 50-ih godina prošlog veka na drugoj lokaciji, čime je ovo mesto izgubilo simboliku progresa koja mu je data 30-ih godina, a da u isto vreme nije realizovano kao spomenički kompleks. 